Click www.researchjournal.co.in/online/subdetail.html to purchase.

International Journal of Commerce and Business Management

Volume 13 | Issue 2 | October, 2020 | 49-56

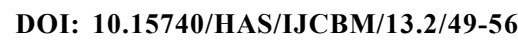

$\Rightarrow$ Visit us : www.researchjournal.co.in

RESEARCH PAPER

\title{
Does supply chain coordination impact supply chain performance? Evidence from dairy industry
}

\author{
Mohd Abdul Muqeet Maaz, Rais Ahmad and Arif Abad
}

Received : 19.05.2020; Revised : 03.09.2020; Accepted : 15.09.2020

\begin{abstract}
The objective of this study is to identify extent of coordination among the supply stakeholders; measure supply chain performance and to study the impact of supply chain coordination on supply chain performance. The study is based on primary data collected from dairy supply chain stakeholders namely farmer-producers, bulk milk coolers (BMC), processing unit, wholesalers and retailers. The data was collected through combination of personal interviews, telephonic interviews and e-mail. The total sample size of this study is 420 spread across 28 firms with each firm representing a total of 15 respondents. Linear regression was performed to study the impact of supply chain coordination on supply chain performance. The results of this study reveal that supply chain coordination positively impacts all the supply chain performance metrics namely efficiency, responsiveness, flexibility and quality. Supply chain coordination has highest impact on supply chain responsiveness followed by supply chain quality, supply chain flexibility and supply chain efficiency. In case of impact of supply chain coordination on overall supply chain performance, there is an evidence of strong impact of supply chain coordination on supply chain performance.
\end{abstract}

KEY WORDS : Supply chain coordination, Supply chain performance, Dairy industry

How to cite this paper : Maaz, Mohd Abdul Muqeet, Ahmad, Rais and Abad, Arif (2020). Does supply chain coordination impact supply chain performance? Evidence from dairy industry. Internat. J. Com. \& Bus. Manage, 13(2) : 49-56, DOI: 10.15740/HAS/IJCBM/ 13.2/49-56. Copyright@2020: Hind Agri-Horticultural Society.

\section{MEMBERS OF THE RESEARCH FORUM}

Correspondence to:

Mohd Abdul Muqeet Maaz, Department of Agricultural Economics and Business Management, Aligarh Muslim University, Aligarh (U.P.)

India

E-mail: mamaaz@myamu.ac.in

Authors' affiliations:

Rais Ahmad and Arif Abad, Department of Agricultural Economics and Business Management, Aligarh Muslim University, Aligarh (U.P.) India

E-mail: drraisahmad@gmail.com; arifabad252@gmail.com 